\title{
Improving student satisfaction through social media marketing activities: The mediating role of perceived quality
}

\author{
Asli Okten Demircioglu ${ }^{a^{*}}$, Feyza Bhatti ${ }^{a}$ and Bashar Ababneh ${ }^{b}$
}

\author{
Article history: \\ Received: September 18, 2020 \\ Received in revised format: \\ October 20, 2020 \\ Accepted: December 29, 2020 \\ Available online: December 29, \\ 2020 \\ Keywords: \\ Social Media Marketing \\ Higher Education \\ Perceived Quality \\ Students' Satisfaction
}

${ }^{a}$ Girne American University, Faculty of Business and Economics, Cyprus

${ }^{b}$ American University of Cyprus, Faculty of Business and Economics, Cyprus

\section{A B S T R A C T}

\begin{abstract}
The connection between education and technology offers an exciting opportunity for universities to utilize social media marketing activities not only to recruit new students or to create brand image and reputation, but also to enhance student satisfaction. Despite having a large number of studies indicating the importance of social media as a tool for student recruitment, the studies on the importance of social media marketing activities (SMMA) for students who are already enrolled are rare. This study aims at examining the relationship between SMMA and student satisfaction, considering perceived quality as a mediator in the higher education sector in North Cyprus. Utilizing a cross-sectional online survey, the data for this study was collected during October- November 2020 from 424 international students enrolled in North Cyprus universities. The model was assessed and the data was analyzed using Structural Equation Model (SEM) in AMOS statistical software. The findings suggest that SMMA has a positive relationship with the perceived quality of education, and perceived quality mediates the relationship between SMMA and student satisfaction positively.
\end{abstract}

\section{Introduction}

In the last two decades, companies had to evolve their traditional marketing strategies with the digital ones to enhance their reach. While the customers enjoyed the benefits of expressing themselves through faster communication tools, companies use the technology as an advantage to attract more customers and get feedback and measure the performance of product/service and the business quicker and less costlier than before. In order to gain competitive advantage and create strong brands the web can be an extremely useful tools for marketers. Moreover, it is mentioned that in order to use the advantages, firms must adopt social media as a channel to provide information to customers; connect with stakeholders and finally to generate sales. As marketing communications become increasingly integrated with the digital space, marketers can use social media to create digital connections with customers effectively. In order to benefit from these advantages, firms must adopt social media to provide information to customers, connect with stakeholders and finally to generate sales (Tiago et al., 2014). According to Sprout Social Index (2019), it is revealed that despite the potential of social media, marketers still have suspicions about its effectiveness. Besides, $47 \%$ of marketers mention that developing social media strategies that support overall business goals is still the first challenge in their organizations. Moreover, $22 \%$ of marketing leaders have concerns that their brand's social media strategy is ineffective. Nevertheless, social media marketing's importance cannot be ignored. Consequently, social media marketing activities should create higher customer relationships and brand loyalty, following customer engagement and satisfaction. Higher education institutions, alike, can leverage social media marketing activities to reach prospective students, create brand image and reputation and also engage with their current students to improve their satisfaction. Particularly with the recent travel restrictions due to Covid19 pandemic, higher education marketing turns into a completely

* Corresponding author.

E-mail address: asokten@gmail.com (A. O. Demircioglu) 
new formation and higher education institutions are entailed to reach their students through the use of the internet in general, and through social media activities in particular.

Higher Education (HE) has evolved tremendously as a result of globalization, economical, technological, and social changes. As a result of these changes, using marketing theories and concepts which have been effectively used in the business world, are now being applied by many universities in order to gain a competitive advantage and international market (HemsleyBrown \& Oplatka, 2006). Marketing of higher education institutions, however, had barely gained any support before the 2000s as it would undermine the academic quality (Constantinides \& Stagno, 2011). The resistance to higher education marketing has weakened with the decreasing government regulation and increased competition among the higher education institutions across the world (Hemsley-Brown \& Oplatka, 2006). Since the 2000s, universities increasingly adopted varying marketing strategies particularly to attract and recruit prospective students. Based on the initial ethical apprehensions regarding the nexus between higher education marketing and academic quality, the relationship marketing strategies that would build and sustain a relationship between the higher education institution and its current, future and past students were considered as the most suitable marketing strategy for higher education (Helgesen, 2008; Gibbs \& Murphy, 2009). Social media marketing activities that can create a collaborative and engaging environment between the higher education institution and its students, therefore can be considered as one of the most appropriate tools that would lead to desired relational marketing strategies.

At the global level, social networking sites and social media have increased in popularity over the last decade, which also revolutionized marketing activities (Hanna, Rohm, \& Crittenden, 2011) and influenced consumer behaviour at every level from obtaining information to post-purchase behaviour including satisfaction (Mangold \& Faulds, 2009). Social media and networking sites are also being used by universities as spaces through which students can interact with their peers and faculty online as well as tools for marketing for prospective students. While prior research has extensively investigated the online marketing strategies of universities (Duesterhaus, 2015) and shown the importance of social media for universities for recruitment of students (Constantinides \& Stagno, 2011; Kuzma \& Wright, 2013), very little is known about the how social media marketing activities of higher education influences the post-purchase behaviour of the students. Although there are mixed results demonstrating the role of social media marketing activities as a recruitment tool for prospective students of higher education institutions (Assimakopoulos et al., 2017; Constantinides \& Stagno, 2011; Hayes, Ruschman \& Walker, 2009; Nyangau \& Bado, 2012; Xiong et al., 2018), its role on current students satisfaction levels is yet to be investigated. Particularly, prior research does not provide an answer to the question 'does social media marketing activities of universities influence the student satisfaction? Does SMMA affect the perceived quality of the education received?' Having this knowledge, however, would increase our understanding of the role of social media marketing in a highly competitive higher education context like North Cyprus, and it would also provide university marketers useful insights on effective strategies to increase student satisfaction.

This study investigates the role social media marketing activities have on student's satisfaction and perceived quality of education among the international students of universities in North Cyprus. These findings have important consequences for management of universities and may give feedback in order to develop effective social media marketing strategies for Higher Education.

\section{Literature Review}

\subsection{Northern Cyprus}

Northern Cyprus, which is a small island economy recognised only by Turkey, has a population of 326.000 (Census,2020). There is a considerable student population registered to a large number of universities: a total 22 universities that can be categorized as private, public and Turkish universities that have a campus in North Cyprus. A total of 103,748 students were studying in North Cyprus during the 2019-2010 academic year. A majority of these students were from Turkey (50,285), followed by international $(41,219)$ and Turkish Cypriot $(12,243)$ students (TRNC Ministry of National Education and Culture, 2020). Despite the fact that North Cyprus has political issues regarding recognition. Today, there is still huge demand for North Cyprus Universities from international students. Comparing the number of universities and students with the population and the scale of the island, the aggressive competition between universities in terms of recruiting and retaining the students is evident, which also highlights the importance of marketing activities and ensuring student satisfaction for the universities. Despite a small number of studies investigating the student satisfaction from various services provided by the universities in North Cyprus (Nadiri, Kandampully \& Hussain, 2009), there are no studies linking the SMMA and student satisfaction, or investigating the pathways such as perceived quality that might affect this relationship.

\subsection{Social Media Marketing Activities}

Regarding the Digital 2020 July Global Snapshot Report, there are 4.57 billion people around the world using the internet now, also there are 346 million new users becoming online within the last 12 months. Despite the increasing usage and interest in social media, its effectiveness on brand sales remains unknown and unpredictable(Kumar et al., 2017). The QS International Student Survey 2019 (ISS) revealed that $85 \%$ of the 75,000 prospective international students use social media as a part of the research process when deciding where to study for Higher Education. This survey picked out that universities 
can reach students with digital marketing tools which are Facebook, Twitter, Websites, Blogs, Whatsapp, Website, Skype and Instagram. Moreover, new digital tools which are virtual college fairs, webinars, web-chats, videos, web-chats are gaining importance to meet with prospective international students. As has been previously reported in the literature, it is indicated that students' information satisfaction is vital to students' choice satisfaction. However, many prospective students experience an information overload and may not be able to effectively compare and contrast college offerings within their choice set (Nurlidai et al., 2010). Consequently, Higher Education Institutions need to design marketing approaches; and consider the unique selling point that would differentiate their offerings from the competition while taking into account what things really matter to the prospective students from different countries (Shanka et al., 2006). Hence, this study will measure whether SMMA has a positive effect on student's satisfaction.

Hypothesis 1:: Social Media Marketing activities has an effect on students' satisfaction.

\subsection{Perceived Quality}

For institutions, creating quality and value provides sustainable success and performance. Therefore, it is vital to improve the perceived quality for Higher Education (HE) as well. While discussing perceived quality, the crucial element is quality of indicators.In the literature,Parasuraman et al. (1988) identifies ten determinants of service quality, namely, accessibility, reliability, responsiveness, competence, courtesy, communication, credibility, understanding the customer, security and tangibles. In the Higher Education (HE) perspective, perceived quality can be managed by gathering information on student's expectations in order to align them as closely as possible with what can be delivered by way of service quality (Hill, 1995). Athiyaman (1997) identifies the relationship between consumer satisfaction and perceived quality in higher education study; the findings of the study is perceived quality is a consequence of consumer satisfaction. Hence, this study will explore the relationship between whether social media marketing activities have a positive effect on perceived quality.

Hypothesis 2: Social Media Marketing activities has effect on perceived quality.

\subsection{Students' Satisfaction}

There are high numbers of studies that have been conducted to understand and identify the variables of students' satisfaction. Student's satisfaction in higher education has been discussed in many dimensions in the literature. The studies revealed that there are many factors and dimensions that take into consideration in order to measure the students' satisfaction; one of the reasons might be that students could have such dramatically different perceptions of the same experience (Appleton-Knapp \& Krentler, 2006). Napoli and Wortman (1998) measure the students' satisfaction on basis of psychological dimensions which are related with life events occurring during the first semester of college, social support, self-esteem, social competence, personal conscientiousness, psychological well-being, and satisfaction with the academic, administrative, and social systems of college);(Marzo, et al.,2005) have measured the students' satisfaction involving personal and institutional factors (teaching methods,course administration, teaching staff,enrolment,infrastructures,satisfaction and loyalty. This study will focus on satisfaction scale and perceived quality scale (Athiyaman, 1997). Moreover, previous studies have almost exclusively focused on popular and well-established brands to study higher education in the United States, UK, Australia and European Union countries. As far as it is searched, no previous research has investigated factors of international students satisfaction in North Cyprus universities. Hence, the objective of this study is to analyze the students' satisfaction in terms of perceived quality and students' satisfaction.

Hypothesis 3: Perceived quality influences on students' satisfaction.

Hypothesis 4: Perceived quality mediates the relationship between Social media marketing activities and students' satisfaction.

The structure of the proposed model that integrates the hypothesized relationships, as well as the moderating effect of perceived quality, is presented in Fig. 1.

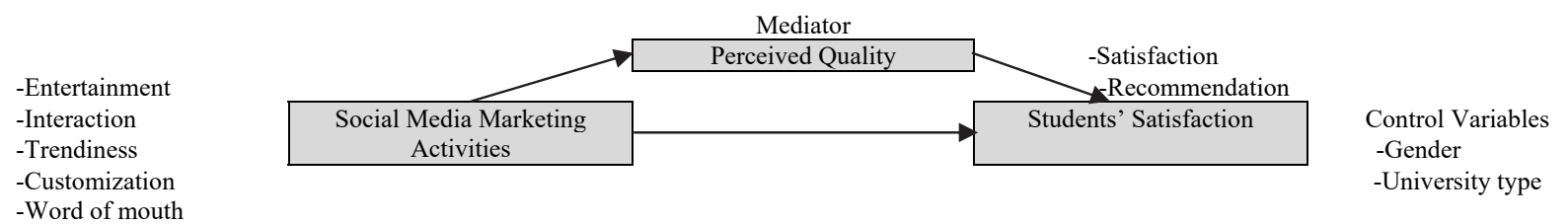

Fig. 1. The structure of the proposed model

\section{Methodology}

This study is conducted in a quantitative approach in order to state the research problems in specific terms. The items of each factor in the questionnaires were created on the basis of literature and revision in the context of the research. In the demographic analysis of data, present the distribution of respondents by gender, age, type of university, level of study and 
nationality based on region and then carry out statistical analysis of research questions. Several scales based on previous literature were used in order to measure each dimension,primarily by using the Cronbach-alpha indicator, including a series of questions that measure the overall satisfaction of the students' satisfaction and perceived quality (Athiyaman, 1997). The conceptual model of social media marketing activities (SMMA) was adopted from Kim and Ko (2012) and included five dimensions which are Entertainment; Interaction; Trendiness; Customization and Word of Mouth.

\section{Results}

The population of this study was international students enrolled in North Cyprus universities. For data collection, an online questionnaire was prepared and shared through social media for a month during October and November 2020. A total of 438 questionnaires were filled by the students, and 424 were complete and used in the analysis for this paper.

Table 1 provides the demographic characteristics of the participants. Majority of the respondents were male (62\%), aged 18$24(65.4 \%)$ and studying in a private university $(88.7 \%)$. The $73.8 \%$ of the respondents were in an undergraduate program, followed by a Master (16.5\%) and PhD programs (8.2\%). Majority of the participants were also from Africa (45.5\%) and Middle East (33.7\%).

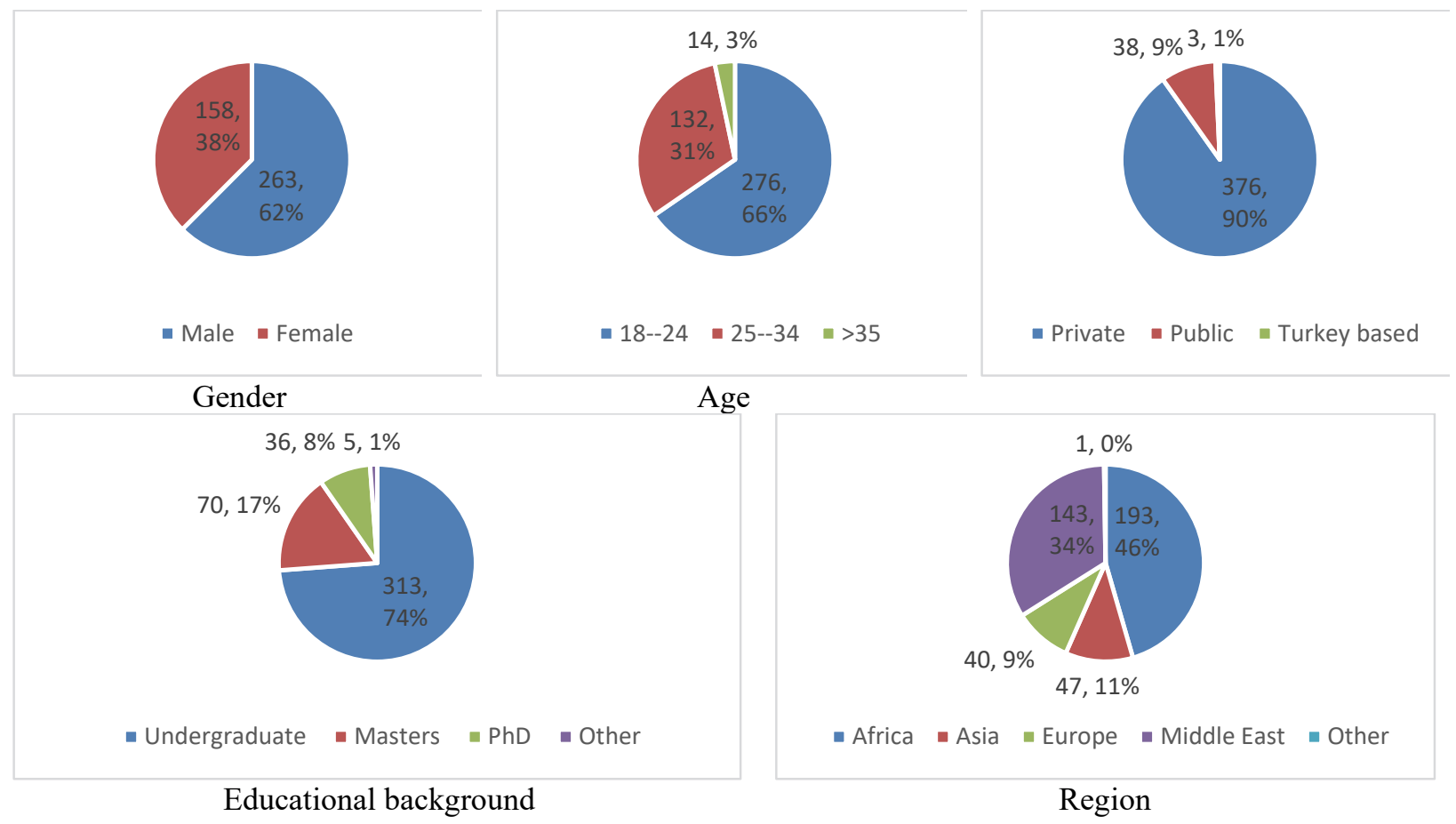

Fig. 1. Sample Characteristics

\subsection{Reliability and Validity}

The reliability of the constructs was assessed by using Cronbach's alpha. As shown in Table 1, the reliability of the constructs were high as the values of all constructs were greater than 0.92 . The overall coefficient alpha scores exceed 0.867 whereby the value can be accumulated to a 0.923 average.Confirmatory factor analysis was conducted to indicate the validity of the constructs. As shown in the same table, the proposed research model fit was excellent as well $(\mathrm{CMIN} / \mathrm{DF}=2.4081>$ and $<3.00 ; \mathrm{SRMR}=.033<.08 ; \mathrm{CFI}=.97>.95 ; \mathrm{RMSEA}=0.058<.06 ;$ PClose $=.064>.05)$. Similarly, the factor loading for all items was greater than 0.692 , the composite reliabilities for each construct were higher than 0.85 , and the average variance extracted (AVE) for all constructs was greater than 0.75 . Therefore, the instruments that have been used in measuring various variables in this study are reliable. For the validity test, this study used convergent validity with a reflective indicator measured by loading factor (correlation between item score/ component score with construct score). The validity of the instrument was seen from the value of convergent validity and discriminant validity. As shown in Table 2, AVE values are all above 0.5 showing good levels of convergent validity confidence in the results of this research. 
Table 1

Measurement model estimation

\begin{tabular}{|c|c|c|c|c|c|c|}
\hline $\begin{array}{l}\text { Construct name and measurement items } \\
\text { Social Media Marketing Activities SMMA }(\alpha=.92)\end{array}$ & Mean & SD & $\lambda$ & $\begin{array}{c}\text { Variance (\%) } \\
47.42878\end{array}$ & $\begin{array}{c}\text { Composite } \\
0.958\end{array}$ & $\begin{array}{l}\text { AVE } \\
0.819\end{array}$ \\
\hline SMMAENT1: Using my university's social media is fun & 3.11 & 0.91 & 0.752 & & & \\
\hline $\begin{array}{l}\text { SMMAENT2: Contents shown in my university's social media seem } \\
\text { interesting }\end{array}$ & 3.28 & 0.91 & 0.871 & & & \\
\hline $\begin{array}{l}\text { SMMAINTR1: My university's social media enables information sharing } \\
\text { with others }\end{array}$ & 3.46 & 0.99 & 0.69 & & & \\
\hline $\begin{array}{l}\text { SMMAINTR2: Conversation or opinion exchange with others is possible } \\
\text { through my university's social media }\end{array}$ & 3.21 & 0.99 & 0.795 & & & \\
\hline $\begin{array}{l}\text { SMMAINTR3: It is easy to deliver my opinion through my university's } \\
\text { social media. }\end{array}$ & 3.07 & 1.1 & 0.781 & & & \\
\hline $\begin{array}{l}\text { SMMATREND1: Contents shown in my university's social media is the } \\
\text { newest information. }\end{array}$ & 3.41 & 1 & 0.698 & & & \\
\hline SMMATREND2:Using my university's social media is very trendy. & 3.16 & 0.96 & 0.781 & & & \\
\hline $\begin{array}{l}\text { SMMACUSTOM1: My university's social media offers customized } \\
\text { information search. }\end{array}$ & 3.13 & 0.97 & 0.89 & & & \\
\hline $\begin{array}{l}\text { SMMACUSTOM2:My university's social media provides customized } \\
\text { service. }\end{array}$ & 3.07 & 1.02 & 0.852 & & & \\
\hline $\begin{array}{l}\text { SMMAWOM1: I would like to pass along information on services from my } \\
\text { university's social media to my friends. }\end{array}$ & 3.26 & 1.02 & 0.82 & & & \\
\hline $\begin{array}{l}\text { SMMAWOM2: I would like to upload contents from my university's social } \\
\text { media on my social media accounts. }\end{array}$ & 3.05 & 1.04 & 0.762 & & & \\
\hline Satisfaction SAT $(\alpha=.94)$ & & & & 64.23 & 0.946 & 0.897 \\
\hline $\begin{array}{l}\text { SATREC1: I will positively advise intending students to attend my } \\
\text { university. }\end{array}$ & 3.31 & 1.08 & 0.92 & & & \\
\hline SATREC2:I will strongly recommend my university to the outside context. & 3.26 & 1.07 & 0.93 & & & \\
\hline SATREC3:I will advise my friends and relatives to come to my university. & 3.27 & 1.15 & 0.918 & & & \\
\hline SATSAT1: I am satisfied with my decision to attend my university. & 3.43 & 1.05 & 0.911 & & & \\
\hline $\begin{array}{l}\text { SATSAT5: I think I did the right thing when I decided to enroll in my } \\
\text { university. }\end{array}$ & 3.38 & 1.13 & 0.8 & & & \\
\hline Perceived Quality PERCQUAL $(\alpha=.92)$ & & & & 79.704 & 0.867 & 0.764 \\
\hline $\begin{array}{l}\text { PERCQUAL1: I am happy with the quality of services provided by my } \\
\text { university. }\end{array}$ & 3.15 & 1.13 & 0.87 & & & \\
\hline $\begin{array}{l}\text { PERCQUAL3: I am generally satisfied with the quality of facilities provided } \\
\text { by the university. }\end{array}$ & 3.26 & 1.09 & 0.88 & & & \\
\hline Bartlett's Test of Sphericity & 0.000 & & & Significant & & \\
\hline KMO Measure & 0.926 & & & & & \\
\hline
\end{tabular}

$\mathrm{CMIN} / \mathrm{DF}=2.4081>$ and $<3.00 ; \mathrm{SRMR}=.033<.08 ; \mathrm{CFI}=.97>.95 ; \mathrm{RMSEA}=0.058<.06 ;$ PClose $=.064>.05$

Note: All loadings are significant at a confidence level of $<.001$.

The measurements of dimensions that form latent variables in the research model are described by Confirmatory factor analysis (CFA) . The latent variables used in this study consist of two second order latent (unobserved) along with seven first order unobserved variables and 18 observed variables as the forming dimensions. Four observed variables were omitted to obtain good model fit (one PERCQUAL and three SAT observed variables). The aim of confirmatory factor analysis is to evaluate whether the data fit hypothesized measurement model. The results of data processing for Confirmatory Factor Analysis are shown in Fig.2, while the description of the numbers from the model feasibility test results is shown in Table 1 above. The results show that the proposed model is fit because all the goodness of fit criteria is at a good level.

Table 2

Discriminant Validity

\begin{tabular}{lccccccc}
\hline & CR & AVE & MSV & MaxR(H) & PERQUAL & SMMA & SAT \\
\hline PERQUAL & 0.867 & 0.764 & 0.823 & 0.867 & $\mathbf{0 . 8 7 4}$ & & \\
SMMA & 0.958 & 0.819 & 0.262 & 0.975 & $0.512 * * *$ & $\mathbf{0 . 9 0 5}$ & \\
SAT & 0.946 & 0.897 & 0.823 & 0.947 & $0.907 * * *$ & $0.510 * * *$ & $\mathbf{0 . 9 4 7}$
\end{tabular}

$\mathrm{AVE}=$ average variance extracted; $\mathrm{CR}=$ composite reliability; diagonal values in bold represent the square root of the AVE.

Significance of Correlations: $\uparrow \mathrm{p}<0.100 ; * \mathrm{p}<0.050 ; * * \mathrm{p}<0.010 ; * * * \mathrm{p}<0.001$ 


\subsection{Structural Equation Modeling: Hypotheses Testing}

The data analysis used in this study is inferential statistical analysis: Structural Equation Modeling (SEM) which is operated by the AMOS statistical software.The SEM technique was chosen because of the nature of the research model and test hypotheses, and due to the mediating and moderating effects.

After confirming the validity and reliability of the measurement model in the first stage of analysis, in this stage, a hypothesized structural model is evaluated. The estimates of the model are presented on Table 3 . All the research hypotheses with their results illustrated in Table 4 and Table 5.

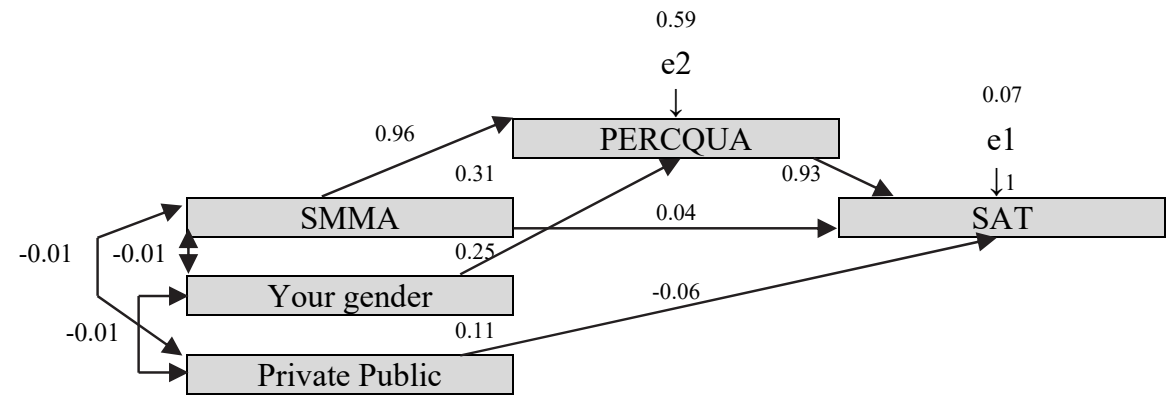

Fig. 2. Structural Model Testing

As Table 3 shows the hypothesized model offered an acceptable fit to data $(\mathrm{CMIN} / \mathrm{DF}=3.220<5.00 ; \mathrm{SRMR}=0.030<.08$; $\mathrm{CFI}=1.00>.95 ; \mathrm{RMSEA}=0.072<.08 ;$ PClose $=0.208>.05$ ). The control variable i.e. gender of the student was negatively related with the PERCQUA indicating lower rates of perceived quality among the female students. The relationship between university type and student satisfaction, on the other hand was not significant.

Table 3

Results of SEM model

\begin{tabular}{lcc}
\hline From $\rightarrow$ To $(\boldsymbol{\beta})$ & PERCQUA & SAT \\
\hline Control Variables & $-.11 * *$ & \\
Gender & & -0.02 \\
University Type & \\
Independent Variables & $.57 * * *$ & 0.02 \\
SMMA & & $.94 * * *$ \\
PERCQUA & & \\
\hline CMIN/DF & & \\
\end{tabular}

$\mathrm{CMIN} / \mathrm{DF}=3.220<5.00 ; \mathrm{SRMR}=0.030<.08 ; \mathrm{CFI}=1.00>.95 ; \mathrm{RMSEA}=0.072<.08 ;$ PClose $=0.208>.05$.

Significance of Correlations: $\uparrow \mathrm{p}<0.100 ; * \mathrm{p}<0.050 ; * * \mathrm{p}<0.010 ; * * * \mathrm{p}<0.001$

Table 4 presents the results; the individual tests the significance of the relationship between the variables. It reveals that (H1) is not supported. The result shows that SMMAs of higher education institutions do not considerably influence the students' satisfaction. On the other hand, $(\mathrm{H} 2)$ is supported $(\beta=0.57, \mathrm{p}<0.001)$ which means that SMMAs of higher education institutions have a positive impact on perceived quality of education services. Moreover, (H3) is supported $(\beta=0.94, \mathrm{p}<$ 0.001) hence, perceived quality of education services have a positive impact on students' satisfaction.

Table 4

Hypothesis Testing

\begin{tabular}{lcc}
\hline & Standardized Estimate & \\
\hline H1 SMMA $\rightarrow$ SAT & 0.02 & Not supported \\
H2 SMMA $\rightarrow$ PERCQUA & $.57 * * *$ & Supported \\
H3 PERQUAL $\rightarrow$ SAT & $.94^{* * *}$ & Supported
\end{tabular}

Significance of Correlations: $\dagger \mathrm{p}<0.100 ; * \mathrm{p}<0.050 ; * * \mathrm{p}<0.010 ; * * * \mathrm{p}<0.001$

Table 5 shows the indirect relationship between SMMA, perceived quality and the satisfaction and indicates that Hypothesis 4 is supported and thus the perceived quality mediates the relationship between SMMA and satisfaction.

Table 5

Indirect Effect

\begin{tabular}{cccccc}
\hline Indirect Path & Unstandardized Estimate & Lower & Upper & P-Value & Standardized Estimate \\
\hline H4 SMMA $\rightarrow$ PERCQUA $\rightarrow$ SAT & 0.885 & 0.762 & 1.007 & 0.001 & $0.535^{* *}$ \\
\hline Significance of Correlations $: \uparrow \mathrm{p}<0.100 ; * \mathrm{p}<0.050 ; * * \mathrm{p}<0.010 ; * * * \mathrm{p}<0.001$ & & &
\end{tabular}




\section{Discussion and Conclusion}

The purpose of this research was to investigate the relationship between SMMA and student satisfaction, as well as testing the mediated relationship of perceived quality in North Cyprus universities. The findings reveal that SMMA of higher education institutions have no direct effect on students' satisfaction. However, the results support that SMMA has a direct impact on perceived quality of education and that perceived quality mediating the relationship between SMMA and international students satisfaction in North Cyprus. Moreover, this survey revealed that gender differences have no positive impact on perceived quality whereas; students who are enrolled in different types of universities have no positive impact on students' satisfaction.

This research contributes to various areas of literature such as marketing and social media studies and studies in higher education. These findings contribute to the previous studies that look at the role of SMMA on consumer behaviour in two ways. In the literature, five stages are identified in the consumer decision process: need recognition, search for information, evaluation of alternatives, and purchase and post-purchase behaviour (Engel et al., 1995). First of all, this study focuses on post-purchase of consumer behaviour focusing on student satisfaction. In the literature, the relationship between SMMA and post-purchase behaviour like satisfaction has been overlooked as most of the studies focuses on the role of SMMA in branding in terms of creating brand awareness, image and loyalty (Bilgin, 2018; Ismail, 2017), brand love (Algharabat, 2017), brand equity (Seo \& Park, 2018) or customer equity (Kim \& Ko, 2012) for corporate brands. Secondly, the study focuses on the higher education institutions. Although there are a large number of studies investigating perceived quality, students' satisfaction and social media marketing activities separately, to the best of our knowledge, there has been no study investigating the relationship between SMMA, perceived quality and satisfaction in the higher education institutions.

Satisfaction of students and perceived quality of education provided are of compelling interest to all stakeholders including students, higher education institutions and the policy-makers. The findings of the study provided a better understanding of the SMMAs of universities and perspective of international students toward their satisfaction and perceived quality, and confirmed that SMMA is an important tool for marketers at higher education institutes, and will also assist marketers to increase perceived quality of education among the students, and improve student satisfaction through perceived quality of education. The SMMA, therefore, is also an effective tool in building a positive perceived quality among the students for higher education institutions. The results of this study may shift universities from traditional marketing activities and develop comprehensive social media marketing plans.

There are several limitations of this research that can be addressed in the future studies. Firstly, it used only two control variables (gender and university type), future studies should consider other control variables that may influence perceived quality in more detail (e.g. teaching quality, course content, reputation). Secondly, this study was a cross-sectional one; thus, the analysis results can only explain individual usage behavior for currently popular social media among the students. The changes in usage would demand a longitudinal approach to capture the possible changes. Longitudinal studies would also be more conclusive of the relationships between the variables measured in this study. Thirdly, future studies should explore how the nationality of the students might affect this relationship as the quality expectations and the satisfaction of the students can vary by their nationality. Moreover, the perceived quality of the other stakeholders should be analyzed such as academic and administrative personnel perspective in future studies in order to deepen the knowledge. Further studies should not only focus on the post-purchase decision process, future studies can also be extended in covering the stages of consumer's decision process to analyze the impact of the social media marketing activities and its relations with perceived quality. Lastly, empirical findings on this study from samples of international students in North Cyprus, where most of the higher education institutions are private, competition among them is very high and student entry requirements are not very high as compared to European and other industrial country higher education institutions. Replicating this study's findings with additional samples of international students in different contexts is needed.

\section{References}

Algharabat, R. S. (2017). Linking social media marketing activities with brand love. Kybernetes.

Appleton-Knapp, S. L., \& Krentler, K. A. (2006). Measuring student expectations and their effects on satisfaction: The importance of managing student expectations. Journal of Marketing Education, 28(3), 254-264.

Assimakopoulos, C., Antoniadis, I., Kayas, O. G., and Dvizac, D. (2017). Effective social media marketing strategy: Facebook as an opportunity for universities. International Journal of Retail \& Distribution Management. 45(5), 532-549.

Athiyaman, A. (1997). Linking student satisfaction and service quality perceptions: the case of university education. European Journal of Marketing, 31(7), 528-540.

Bilgin, Y. (2018). The effect of social media marketing activities on brand awareness, brand image and brand loyalty. Business \& Management Studies: An International Journal, 6(1), 128-148.

Census XLS,TRNC General Population and Housing Unit (Retrieved 2020, October 10 from http://nufussayimi.devplan.org/Census\%202006.pdf )

Constantinides, E., \& Stagno, M.C.Z. (2011). Potential of the social media as instruments of higher education marketing: a segmentation study, Journal of Marketing for Higher Education, 21(1), 7-24. 
Duesterhaus, A. (2015). Strengthening brand positioning through price transparency in higher education. Journal of Brand Strategy, 4(1), 58-69.

Digital 2020 July Report (Retrieved March 25,2020 from on:https://www.smartinsights.com/social-media-marketing/socialmedia-strategy/new-global-social-mediaresearch/\#: :text=More $\% 20$ than $\% 20$ half $\% 20$ of $\% 20$ the, $5.15 \% 20$ billion $\% 20$ unique $\% 20$ mobile $\% 20$ users)

Engel, J.F., Blackwell, R.D., \& Miniard, P.W. (1995). Consumer Behavior, $8^{\text {th }}$ ed., The Dryden Press, New York, NY.

Gibbs, P., \& Murphy, P. (2009). Implementation of ethical higher education marketing. Tertiary Education and Management, 15(4), 341-354.

Hemsley-Brown, J., \& Oplatka, I. (2006). Universities in a competitive global marketplace: a systematic review of the literature on higher education marketing. International Journal of Public Sector Management, 19, 316-338.

Hanna, R., Rohm, A., \& Crittenden, V. L. (2011). We're all connected: The power of the social media ecosystem. Business Horizons, 54, 265-273. http://dx.doi.org/10.1016/i.bushor.2011.01.007

Hayes, T. J., Ruschman, D., \& Walker, M. M. (2009). Social networking as an admission tool: A case study in success. Journal of Marketing for Higher Education, 19(2), 109-124.

Helgesen, Ø. (2008). Marketing for higher education: A relationship marketing approach. Journal of Marketing for Higher Education, 18(1), 50-78.

Hill, F.(1995). Managing service quality in higher education: The role of the student as primary consumer. Quality Assurance in Education, 3, 10-21.

Ismail, A. R. (2017). The influence of perceived social media marketing activities on brand loyalty: The mediation effect of brand and value consciousness. Asia Pacific Journal of Marketing and Logistics, 29(1), 129-144.

Kim, A. J., \& Ko, E. (2012). Do social media marketing activities enhance customer equity? An empirical study of luxury fashion brands. Journal of Business Research, 65(10), 1480-1486.

Kumar, V., Choi, J. B., \& Greene, M. (2017). Synergistic effects of social media and traditional marketing on brand sales: capturing the time-varying effects. Journal of the Academy of Marketing Science, 45(2), 268-288.

Kuzma, J. M., \& Wright, W. (2013). Using social networks as a catalyst for change in global higher education marketing and recruiting. International Journal of Continuing Engineering Education and LifeLong Learning, 23(1), 53-66.

Mangold, W. G., \& Faulds, D. J. (2009). Social media: The new hybrid element of the promotion mix. Business Horizons, 52, 357-365.http://dx.doi.org/10.1016/j.bushor.2009.03.002

Marzo-Navarro, M., Iglesias, M., \& Torres, M. (2005). A new management element for universities: satisfaction with the offered courses. International Journal of Educational Management, 19(6), 505-526.

Parasuraman, A., Zeithaml, V., \& Berry, L. (1988). SERVQUAL: A multiple item scale for measuring customer perceptions of service quality. Journal of Retailing, 64(1), 12-37.

Seo, E. J., \& Park, J. W. (2018). A study on the effects of social media marketing activities on brand equity and customer response in the airline industry. Journal of Air Transport Management, 66, 36-41.

Sprout Social Index (2019).(Retrieved October 12,2020 from https://sproutsocial.com/insights/data/2019-index/)

Shanka, T., Quintal, V., \& Taylor, R. (2006). Factors influencing international students' choice of an education destinationA correspondence analysis. Journal of Marketing for Higher Education, 15(2), 31-46.

The QS International Student Survey 2019 (ISS). (Retrieved January 25,2020 from International Student Survey https://www.internationalstudentsurvey.com/international-student-survey-2019/)

TRNC Ministry of National Education and Culture. (2020).(Retrieved October 22, 2020 from Higher Education and Foreign Relations https://yobis.mebnet.net)

Tiago, M. T. P. M. B., \& Veríssimo, J. M. C. (2014). Digital marketing and social media: Why bother? Business Horizons, 57(6), 703-708.

Xiong, L., Alsadoon, A., Maag, A., Prasad, P. W. C., Hoe, L. S., \& Elchouemi, A. (2018). Rise of Social Media Marketing: A Perspective on Higher Education. 2018 13th International Conference on Computer Science \& Education (ICCSE), Colombo, 2018, pp. 1-6, doi: 10.1109/ICCSE.2018.8468683.

Zeithaml, V.A. (1988). Consumer perceptions of price, quality, and value: A means-end model and synthesis of evidence. Journal of Marketing, 52(3), 2-22.

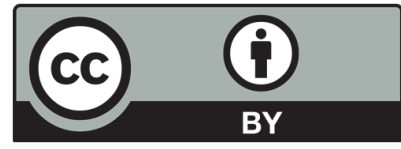

(C) 2021 by the authors; licensee Growing Science, Canada. This is an open access article distributed under the terms and conditions of the Creative Commons Attribution (CC-BY) license (http://creativecommons.org/licenses/by/4.0/). 